\title{
The Influence of Marketing Mix on Tourists' Decision to Stay at Hotels in Denpasar
}

\author{
Ni Nyoman Rusmiati ${ }^{*}$, Ida I Dewa Ayu Manik Sastri ${ }^{2}$, Luh Kade Datrini ${ }^{3}$ \\ Universitas Warmadewa, Denpasar-Bali, Indonesia \\ \{rusmiatiunwar@gmail.com ${ }^{1}$ \}
}

\begin{abstract}
The objective of this study is to measure the simultaneous and partial influences of a marketing mix (product, price, promotion and place / location) on tourists' decisions to stay at hotels in Denpasar. The data of this study were analysed using quantitative analysis technique with a multiple linear regression, f-test and t-test. The results showed that shown by the result of the f-test, the value of the f-count was 34.578. The result is greater than the f-table which was 2.47 with sig $0.000<0.05$; thus, $\mathrm{HO}$ is rejected and $\mathrm{Ha}$ is accepted. Hence, product, price, promotion, and location / place simultaneously have a positive and significant influence on the tourists' decisions to stay at hotels in Denpasar. Then, based on the t-test results, the product variable showed that the t-count was 2.351 and was greater than the $\mathrm{t}$-table value which was 1.985 ; thus, $\mathrm{H} 0$ is rejected and $\mathrm{Ha}$ is accepted. Therefore, product has a positive and significant influence on the tourists' decisions to stay at the hotels. Price variable showed that t-count value was 3.995 and was greater than that of t-table which was 1.985 ; therefore, $\mathrm{H} 0$ is rejected and $\mathrm{Ha}$ is accepted. This implies that the price has a positive and significant influence on the tourists' decisions to stay. The promotion variable showed that the t-count value was 6.449 and was greater than t-table value which was 1.985; therefore, $\mathrm{H} 0$ is rejected and $\mathrm{Ha}$ is accepted. This also shows that promotion has a positive and significant influence on the tourists' decisions to stay. The last, the variable of location / place showed that tcount value was 4,867 and was greater than the t-table value which is 1,985 ; thus, $\mathrm{H} 0$ is rejected and $\mathrm{Ha}$ is accepted. This also means that the location / place has a positive and significant influence on the tourists' decisions to stay at hotels in Denpasar.
\end{abstract}

Keywords: Product; Price; Promotion; Place; Tourist's Decision

\section{Introduction}

Hotels constitute the type of accommodation making use of part or all of a building to provide lodging, food, beverage and other supporting services which are commonly managed commercially. Established on the definition, the main goal of a hotel business is to provide lodging, which is usually accompanied by additional services and facilities such as television, telephone, air conditioning and others. Denpasar, as a city, has a number of hotels that continue to increase in number from year to to year. The increasing condition of the hotel development in the city is inseparable to the increasing number of tourists visiting Bali. As a consequence, it requires the company management to have a competitive advantage. A competitive advantage is fundamentally needed by a company in competing with other companies. To support this, a company can take advantage of two or more marketing activities in asimultaneous manner, which is known as the marketing mix. Marketing mix represents a 
combination of variables or activities serving as the core of a marketing system, a variable that can be controlled by the company to influence the reactions of buyers or consumers [1].

The first variable in the marketing mix is product management. Product factor has an influence on the decision of tourists to stay overnight if the products offered can satisfy their wants and needs.

Price refers to the amount of money or obligation that must be paid by a consumer to get a product or service they want. In fact, price can affect the consumer considerations to purchase a product or service [2].

Promotion covers the company activities to influence consumers to make requests for their products, which are then maintained and developed [3]. By carrying out effective and attractive promotional activities, the attention of consumers can be attracted and can cause them to have confidence in the products offered so that in the end they will make a decision to buy the product.

Distribution decision concerns the ease of access toward services for potential customers. The decision includes physical location decision, decision regarding the use of intermediaries to increase service accessibility for customers, and non-location decision that is made for the sake of service availability [4]. With a strategic location and close proximity, consumers can be attracted to make decisions to take advantages of a product in the form of goods or services.

In the days before the emergence of Covid-19, the rate of competition between hotels in Denpasar was quite high, each implementing different maerketing strategies. In the early of 2020, the beginning when the Coronavirus Desease 2019 broke out in Indonesia, the occupancy rate of hotels in the city of Denpasar has decreased by up to $30 \%$. Prior to that time, many Chinese people visited Denpasar, Bali. Since the outbreak of the Covid-19 pandemic, not only Chinese citizens have stopped visiting Indonesia but also many other countries have urged their citizens to postpone trips abroad, including to Indonesia, and including the city of Denpasar. In the early of April 2020, a number of hotels of throughout Bali were closed for a temporal time for the sake of stopping the spread of the corona virus. In addition, the government, including the Provincial Government of Bali, began to implement the Community Activity Restriction program. As a result, the entire hotel was closed. In July 2020, tourism in Bali began to reopen, but it was specifically made for local and domestic tourists; tourism activities began to be redeveloped. In order to ensure the services offered by companies, there is a need to apply a marketing mix, as a sales marketing and strategy. This kind of marketing concept is expected to support the efforts to increase the tourists' decisions to stay at hotels in Denpasar.

The focus of the study in this research is on the variables of product, price, promotion, and place. This research is focused on these variables because it is suspected that they have a significant influence on tourists' decisions to stay at hotels in Denpasar.

\section{Formulation of Problems}

This study is conducted to measure the influence of the Marketing Mix (product, price, promotion and place) on tourists' decisions to stay at hotels in Denpasar, either partially or simultaneously. Therefore, this research problem is formulated as: "Does the Marketing Mix (product, price, promotion and place) influence the tourists' decisions to stay at hotels in Denpasar, either simultaneously or partially?"

\section{Objectives and Significances of the Study}


Based on the problem formulation above, the objective to be achieved in this study is to reveal the influence of the Marketing Mix (product, price, promotion and place) on tourists' decisions to stay at hotels in Denpasar, either partially or simultaneously. The results of this study are expected to provide benefits for hotel management as information regarding the variables within marketing mix having the potential to affect the tourists' decisions to stay at hotels in Denpasar.

\section{Urgency of the Study}

Competition among hotels in Denpasar has been intense. However, the outbreak of the corona virus starting in the town of Wuhan in China has brought a significant and negative impact on the decline in the occupancy rates of hotels in Denpasar. In addition, the implementation of the Community Activity Restriction (PKM) program ending in July 2020 has made tourism reopen, especially for local and domestic tourists. Therefore, a new strategy is needed to encourage the marketing and sales of hotel products and services amidst the limited community activities. Therefore, a scientific study focusing on the influences of the marketing mix on the tourists' decisions to stay at hotels in Denpasar has a crucial role, because it is hypothesised that the variables within the marketing mix will have a significant influence on the tourists' decisions to stay at hotels.

\section{Literature Review}

\section{Marketing}

Marketing comprises a combination of interconnected activities to determine consumer needs through the creation, offering and exchange of valuable products and services and developing promotions, distribution, services and prices resulting the proper satisfaction of the consumer needs at certain profit levels [5].

Marketing includes a series of institutional activities and the process of creating, communicating, delivering, and exchanging offers that are of value to customers, clients, partners and the wider community [4].

\section{Marketing Mix}

In a marketing study, there is a strategy called marketing mix. The marketing mix has a crucial role for companies in influencing consumers to make purchase of the products or services they offers, as well as for the success of a good marketing of both products or services. The elements of the marketing mix include elements of all the variables that the company can control in order to satisfy target customers.

Marketing mix is a combination of variables or activities serving as the core of the marketing system, the variables that can be controlled by the company to influence the reactions of purchasers or consumers [1].

Variables within Marketing Mix are described in the following part:

- Product

A product is a form of service organisation offering that is intended to achieve organisational goals through customer needs and wants satisfaction. In this context, products can be anything (both physical and non-physical) that can be offered to potential customers to fulfill certain needs and wants [4].

- Price 
Price refers to the amount of money or obligation that must be paid by consumers to get a product or service that the consumer wants. Price can be a consideration for consumers to purchase a product or service [2].

- Promotion

Promotion is a series of activities carried out by companies to communicate the benefits of their products in order to convince potential target customers to make purchase of them. Promotion becomes a factor that determines the success of a marketing program [6].

\section{Place}

Distribution decision concerns the ease of access to services for potential customers. The decision includes physical location decision, decision regarding the use of intermediaries to increase service accessibility for customers, and non-location decision that is made for the sake of service availability [4].

A thorough consideration in determining the location includes the following factors:

- Access, such as easily accessible locations to public means of transportation.

- Visibility, such as locations that can be seen clearly.

\section{Purchasing Decision}

The decision to make use of services can be divided into three main stages: prepurchase, getting together between seller and prospective purchaser and postencounter services [7].

The purchasing decision process begins when a candidate purchaser realises there is a problem of need (problem recognition), in which, they realise that there is a dissimilarity between the actual condition and the condition they want. Afterwards, a consumer whose interest in buying begins to arise will be motivated to seek more information about the product so as to get a collection of brands with various features [8].

Studies on the influences of the marketing mix on tourists' decisions to stay at hotels have been conducted before. Therefore, the present one is conducted on the basis of previous studies serving as a basis as well as references for determining the limits of the study in the present research.

The first research was the one conducted to measure the influence of service marketing mix on consumers' decisions to stay at Hotel Syariah Arini Surakarta [9]. In a specific way, the purpose of the study was to reveal the influence of products, price, promotion, place, processe, people and physical evidence on consumers' decisions to stay at the Hotel Syariah Arini. There were 120 respondents in the research sample who were selected using the Roscoe method.

The second study was conducted to determine the influence of marketing mix on the consumers' decisions to stay at the Inna Grand Bali Beach Hotel [10]. The specific objective of the research was to determine the simultaneous and partial influence of the marketing mix variables consisting of product, price, place, promotion, people, physical facilities, and processes on the decision of consumers to stay at the Inna Grand Bali Beach Hotel.

Two previous studies used seven variables in the marketing mix influencing tourists' decisions to stay at hotels. Meanwhile, this research examines the problem of consumers' decisions to stay at hotels only with the variables within the marketing mix because it is suspected that only these four variables have a significant effect on tourists' decisions to stay at hotels in Denpasar. This difference represents the state-of-the-art of this research.

\section{Hypothesis}


The basic handle of this research is the assumption that the marketing mix (product, price, promotion and place) has a positive and significant influence on tourists' decisions to stay at hotels in Denpasar, either partially or simultaneously.

\section{Method}

\section{Sample Determination Method}

The research is conducted at hotels in Denpasar. The sample of respondents was selected according to Roscoe's sampling theory. If the research data analysis is carried out using multivariate (correlation or multiple regression, for example), then the minimum sample size is 5-10 times the number of indicators being studied. In this study there are 100 respondents.

\section{Data Collection Method}

The data collection of this research was carried out using questionnaire. The questionnaire is a method of collecting tangible data through the distribution of a number of questions / statements related to the problem under study to respondents. The questionnaire in this study uses choices form, which means that the respondent has been provided with choices in filling out the questionnaire.

\section{Data Analysis Technique}

- Classic assumption testing

An ideal regression model is reflected in the one that is free from the problems of the classical assumption test. In this study, the normality test, multicoleniarity and heteroscedasticity will be carried out using SPSS (Statistical Product and Service Solutions).

- Multiple linear regression testing

In this study, multiple linear regression test is used to analyse the influence of the marketing mix on tourists' decisions to stay overnight. The multiple linear regression is expressed in the form of a line equation (Sugiyono, 2017: 188) as follows:

$\mathrm{Y}=\alpha+\beta 1 X 1+\beta 2 X 2+\beta 3 X 3+\beta 4 X 4$

- Hypothesis testing

1. Simultaneous significance test (F-test)

The F-statistical test is basically used to show whether all the independent variables included in the model simultaneously have an influence on the dependent variable.

2. Individual parameter significance test (Statistical t-test)

\section{Results and Discussion}

\section{Classic Assumption Test}

The regression model is said to be a functional model if it is free from classical statistical assumptions. A multiple linear regression model theoretically will produce the accurate estimator parameter values if it meets the requirements of the classic regression assumptions, namely: normality, multicollinearity, and heteroscedasticity tests. From the results of the normality test shows there is a pattern in the data in the form of a plot spreading around the 
diagonal line and following the direction of the diagonal line. The multicollinearity test result shows that there is no independent variable having a tolerance value less than 0.10 and also that there is no independent variable having a VIF value of more than 10 . Therefore, the regression model is free from multicollinearity symptoms. Heteroscedasticity testing was carried out using the Glesjer method. The analysis results show that the independent variables used in this study do not significantly influence the dependent variable, namely absolute error; and thus, this research is free from heteroscedasticity symptoms.

\section{Multiple Linear Regression Analysis}

The results of this analysis refer to the results of the effect of product variables (X1), price (X2) promotion (X3), and location / place (X4) on tourists' decisions to stay overnight (Y). The results of regression analysis using the Statistical Package of Social Science (SPSS) program version 21.0 are presented in the following table.

Table. 1. Summary of the Results of Multiple Linear Regression Analysis

\begin{tabular}{|c|c|c|c|c|}
\hline \multirow{2}{*}{ Variable } & \multicolumn{2}{|c|}{ Regression Coefficient } & \multirow[b]{2}{*}{ t } & \multirow{2}{*}{ Sig } \\
\hline & B & Std. Error & & \\
\hline Product (X1) & 265 &, 113 & 2,351 & 021 \\
\hline Price (X2) & ,368 & ,092 & 3,995 &, 000 \\
\hline Promotion (X3) &, 595 & 092 & 6,449 &, 000 \\
\hline \multirow[t]{6}{*}{ Place/Location (X4) } &, 544 &, 112 & 4,867 & 000 \\
\hline & \multirow{2}{*}{\multicolumn{2}{|c|}{$\begin{array}{c}\text { (Constant): }-6,371 \\
\text { F-Statistics: } 34,578\end{array}$}} & & \\
\hline & & & & \\
\hline & \multicolumn{2}{|c|}{ Sig F: 0.000} & & \\
\hline & \multicolumn{2}{|c|}{$\mathrm{R}^{2}: 0,593$} & & \\
\hline & \multicolumn{2}{|c|}{$\mathrm{R}: 0,770$} & & \\
\hline
\end{tabular}

Based on the table above, the multiple linear regression equation is made as follows.

$\mathrm{Y}=-6,371+0,265 \mathrm{X} 1+0,368 \mathrm{X} 2+0,595 \mathrm{X} 3+0,544 \mathrm{X} 4$

In which:

$\mathrm{Y}=$ tourists' decisions to stay

$\mathrm{X} 1=$ product, $\mathrm{X} 2$ = price, $\mathrm{X} 3=$ promotion, $\mathrm{X} 4+$ place $/$ location

The multiple linear regression equation shows the direction of each independent variable to the dependent variable. The multiple linear regression equation is explained as follows:

The constant value of -6.371 shows that if the values of product, price, promotion and location / place are equal to 0 (zero), then the decision of tourists to stay at hotels in Denpasar will decrease by -6.371 .

$\mathrm{X} 1=+0.265$ indicates that the product has a positive influence on tourists' decisions to stay at hotels in Denpasar; if the product is getting better, the decision of tourists to stay will increase by 0.265 .

$\mathrm{X} 2=+0.368$ shows that price has a positive influence on tourists' decisions to stay at hotels in Denpasar; if the price is affordable, the decision of tourists to stay overnight will increase by 0.368 .

$\mathrm{X} 3=+0.595$ indicates that promotion has a positive influence on tourists' decisions to stay at hotels in Denpasar; if the number of promotions is higher, the decision of tourists to stay will increase by 0.595 . 
$\mathrm{X} 4=+0.544$ indicates that location / place has a positive influence on tourists' decisions to stay at hotels in Denpasar; if the location / place is getting more strategic, the decision of tourists to stay overnight will increase by 0.544 .

\section{F-test Results}

Based on the analysis results in the table above, it is obtained that the value of $\mathrm{F}_{\text {count }}$ (34.5678) $>F_{\text {table }}(2.47)$ with a significance value of $F$ is $0.000<0.05$, then $\mathrm{H}_{0}$ is rejected. This means that the variables of product $\left(\mathrm{X}_{1}\right)$, price $\left(\mathrm{X}_{2}\right)$, promotion $\left(\mathrm{X}_{3}\right)$ and place/location $\left(\mathrm{X}_{4}\right)$ simultaneously have a positive and significant influence on tourists' decisions to stay (Y) at hotels in Denpasar.

\section{t-Test Results}

Partial test (t-test) is used to measure the effect of each independent variables (product, price, promotion and location / place) on the dependent variable (tourists' decisions to stay) partially or individually. From the table above, the t-test results of all independent variables, namely $\mathrm{t} 1, \mathrm{t} 2, \mathrm{t} 3, \mathrm{t} 4$ are greater than the $\mathrm{t}$-table, so the marketing mix (product, price, promotion and place) partially has a positive and significant influence on tourists' decisions to stay at hotels in Denpasar.

\section{Conclusion}

Based on the t-test results, the product variable showed that the t-count was 2.351 and was greater than the t-table value which was 1.985; thus, $\mathrm{HO}$ is rejected and $\mathrm{Ha}$ is accepted. Therefore, product has a positive and significant influence on the tourists' decisions to stay at the hotels. Price variable showed that $t$-count value was 3.995 and was greater than that of $t$ table which was 1.985; therefore, $\mathrm{H} 0$ is rejected and $\mathrm{Ha}$ is accepted. This implies that the price has a positive and significant influence on the tourists' decisions to stay. The promotion variable showed that the $t$-count value was 6.449 and was greater than t-table value which was 1.985; therefore, $\mathrm{H} 0$ is rejected and $\mathrm{Ha}$ is accepted. This also shows that promotion has a positive and significant influence on the tourists' decisions to stay. The last, the variable of location / place showed that $t$-count value was 4,867 and was greater than the $t$-table value which is 1,985; thus, $\mathrm{H} 0$ is rejected and $\mathrm{Ha}$ is accepted. This also means that the location / place has a positive and significant influence on the tourists' decisions to stay at hotels in Denpasar.

Recommendations of this study aimed at the hotel are The hotel design should be redesigned to make it look more unique and Balinese nuanced architecture is added to it. Lodging rental prices should be adjusted to make it more affordable for visiting tourists so that they can match their financial capabilities. Hotels in Denpasar should more often send emails and promotions via social media to tourists in order that they can find out what promotions the hotel is giving. Furthermore hotels in Denpasar should install directions near the hotel so that tourists who visit can be helped.

The output of this research provides guidance in an effort to enhance tourists' decisions to stay at hotels in Denpasar, and the results of the research will also be published in a proceeding to be published by Atlantis Press indexed by the Web of Science (Scopus Indexed Proceeding). 


\section{References}

[1]. $\quad$ S. Assauri, “Manajemen Pemasaran.” Jakarta: PT Raja Grafindo Persada, 2017

[2]. B. Alma, "Manajemen Pemasaran dan Pemasaran Jasa." Bandung: Alfabeta, 2014.

[3]. S. Assauri, “Manajemen Pemasaran.” Jakarta: Rajawali Pers, 2013.

[4]. F. Tjiptono, "Pemasaran Jasa - Prinsip, Penerapan, dan Penelitian." Yogyakarta: Andi, 2014.

[5]. R. M. Pandia, Kadunci, and D. C. Hutagalung, "Pengaruh Kualitas Produk Dan Harga Terhadap Proses Keputusan Pembelian Konsumen Produk Air Mineral Aqua." J. Penelitian dan Pengembangan Humaniora: Epigram, vol. 14. no. 1, 2017.

[6]. R. Martjiono, S. P. Santoso, A. Aprillia, and M. Remiasa, "Analisa Pengaruh Bauran Pemasaran (7P) Terhadap Keputusan Pembelian Di Rumah Makan Kakkk, Ayam Geprek!!!.” J. Hospitality dan Manajemen Jasa, vol. 4, no. 2, 2016

[7]. C. Lovelock, J. Wirtz, and J. Mussry, "Pemasaran Jasa. edisi 7." Jakarta: Erlangga, 2011

[8]. O. Nofri, and A. Hafifah, "Analisis Perilaku Konsumen Dalam Melakukan Online Shopping Di Kota Makassar.” J. MINDS (Manajemen Ide dan Inspirasi), vol. 5, no. 1,2018

[9]. K. Dewi, and D. C. Triono, "Pengaruh Bauran Pemasaran Jasa Terhadap Keputusan Menginap Konsumen Pada Hotel Syariah Arini Surakarta." Digital Repository Perpustakaan IAIN Surakarta, 2016.

[10]. N. W. Awinasi, and N. M. Rastini, "Pengaruh Bauran Pemasaran Terhadap Keputusan Menginap Pada Hotel Inna Grand Bali Beach Sanur." E-Jurnal Manajemen, vol. 7, no. 8, pp. 4297-4324, 2018. 